\title{
Post-cranial remains of 'coelurosaurs' (Dinosauria, Theropoda) from the Late Jurassic of Tanzania
}

\author{
OLIVER W. M. RAUHUT* \\ Institut für Paläontologie, Museum für Naturkunde, Humboldt-Universität, Invalidenstraße 43, \\ D-10115 Berlin, Germany
}

(Received 19 February 2004; accepted 7 September 2004)

\begin{abstract}
Small theropod post-cranial material from Tendaguru, Tanzania, the only known Late Jurassic theropod locality in the Southern Hemisphere, is reviewed. Material originally described as 'coelurosaurs' includes at least one taxon of basal tetanuran and one taxon of small abelisauroid. Together with the abelisauroid Elaphrosaurus and the presence of a larger ceratosaur in Tendaguru, this material indicates that ceratosaurs were an important faunal element of Late Jurassic East African theropod faunas. One bone furthermore shares derived characters with the holotype of the poorly known Middle Jurassic Australian theropod Ozraptor and allows the identification of the latter as the oldest known abelisauroid, thus indicating an early divergence of ceratosaurids and abelisauroids within ceratosaurs. Abelisauroids might have originated in Gondwana and represent important faunal elements of Cretaceous Gondwanan theropod faunas in general.
\end{abstract}

Keywords: Jurassic, Gondwana, Theropoda, diversity, biogeography.

\section{Introduction}

Our knowledge of theropod dinosaur faunas from Gondwana has rapidly improved in the past twenty years. The description of numerous new taxa and identification of new groups have greatly changed our understanding of Cretaceous theropod evolution and biogeography (e.g. Bonaparte, 1985, 1991a, 1996; Sereno et al. 1994, 1996, 1998; Coria \& Salgado, 1995; Novas, 1996, 1997; Sampson et al. 1998; Sampson, Carrano \& Forster, 2001). Whereas Late Cretaceous Laurasian theropod faunas are dominated by coelurosaurs (tyrannosaurids, dromaeosaurids, ornithomimosaurs, oviraptorosaurs, therizinosaurs, etc.), Cretaceous theropod communities from the Southern Hemisphere are now known to consist of a mixture of a diverse assemblage of highly derived basal theropods (abelisaurs), several groups of basal tetanurans, and rare coelurosaurs (e.g. Rauhut, 1995, 1999; Bonaparte, 1996; Sereno et al. 1996, 1998; Novas, 1997). Unfortunately, however, the origin of the Cretaceous theropod faunas in the Southern Hemisphere is still poorly understood, mainly due to the poor Jurassic dinosaur record from Gondwana.

The German Tendaguru expeditions from 1909 to 1913 still represent the greatest effort to unravel the Late Jurassic history of dinosaurs in Africa and they yielded the most diverse dinosaur faunas from the Jurassic of the Southern Hemisphere (Maier, 2003).

* Present address: Bayerische Staatssammlung für Paläontologie, Richard-Wagner Straße 10, 80333 München, Germany; e-mail: owmrauhut@hotmail.com
Whereas the expeditions resulted in the discovery of thousands of specimens of sauropods, stegosaurs and ornithopods, theropods are rather poorly represented (Janensch, 1914; Zils et al. 1995). Apart from the partial skeleton of Elaphrosaurus (Janensch, 1920, 1925, 1929), only isolated elements have been found, and theropod diversity and faunal composition in the Tendaguru beds is still poorly known, despite the fact that several taxa have been named on the basis of this material (Janensch, 1920, 1925).

Elaphrosaurus bambergi Janensch, 1920 was considered a coelurosaur by Janensch (1925) and later referred to the Ornithomimidae by Nopcsa (1928). This view was widely accepted until the early 1990 s (e.g. Russell, 1972; Russell, Béland \& McIntosh, 1980; Galton, 1982; Barsbold \& Osmólska, 1990; Rich \& Vickers-Rich, 1994), when the discoveries of abelisaurs in South America and more rigorous phylogenetic analyses led to the recognition of this taxon as a basal ceratosaurian and probably abelisaurian theropod (Holtz, 1994, 2000; Rauhut, 1998, 2003a). Janensch (1925) furthermore described three isolated small theropod tibiae from the Tendaguru beds without formal specific designation as 'Coelurosaurier A', 'Coelurosaurier B' and 'Coelurosaurier C'. Janensch used the term 'coelurosaur' in the traditional sense to denominate small theropod dinosaurs, and the meagre small theropod material from Tendaguru is of great potential interest for understanding the origin, interrelationships and biogeography of small Gondwanan theropods in the Late Jurassic and Cretaceous. 


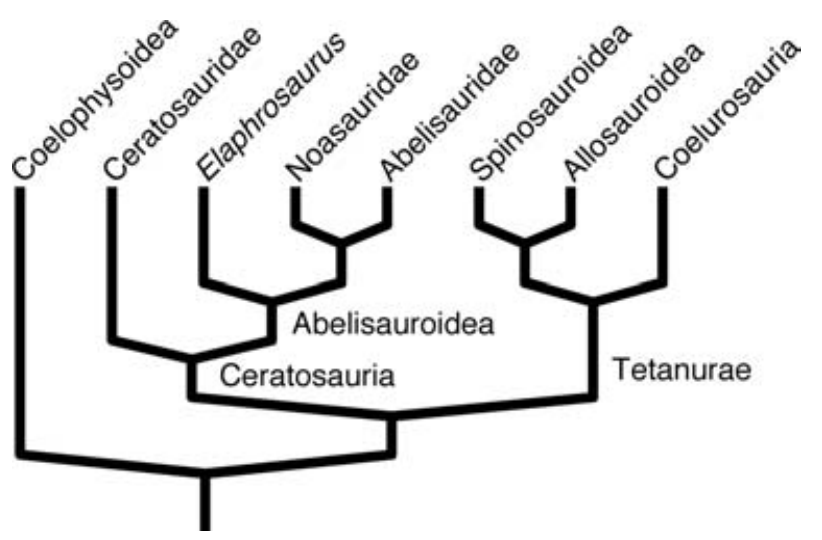

Figure 1. Generalized cladogram demonstrating the relationships of the taxa mentioned in the text. Based on Rauhut (2003a) and Wilson et al. (2003).

The purpose of the present paper is to re-evaluate the small theropod material from Tendaguru in the light of current understanding of theropod systematics.

\section{Materials and methods}

Only the post-cranial elements will be taken into account here; the more abundant tooth material from Tendaguru will be reviewed in a separate work (Rauhut \& Heinrich, unpub. data). Apart from the partial skeleton of Elaphrosaurus, only a few skeletal elements of small theropod dinosaurs are present in the material from Tendaguru. Among this material, the tibiae originally described by Janensch (1925) are the most informative elements; the rest of the material consists of a poorly preserved distal end of a left ischium, two fragmentary fibulae, and several rib fragments. Most of the material is derived from the Middle Saurian Bed and is thus of probable late Kimmeridgian age (Aberhan et al. 2002), but a few elements, most notably the tibia MB.R.1751 and the distal end of an ischium, MB.R.1756, are from the Upper Saurian Beds and thus of latest Tithonian to Berriasian age (Aberhan et al. 2002). Comments on other small theropod material from the Southern Hemisphere are based on personal observations and published accounts. The phylogenetic position of the theropod remains is evaluated on the basis of published analyses of theropod interrelationships (Fig. 1; e.g. Sereno, 1999; Holtz, 2000; Rauhut, 2003a) and comparisons with other taxa of known phylogenetic position. (MB: Museum für Naturkunde, HumboldtUniversität zu Berlin, Germany.)

\section{3. 'Coelurosaur' material from Tendaguru}

In the following, the three small theropod tibiae from Tendaguru will be evaluated, because this is the material on which Janensch (1925) based his 'Coelurosaurier A,
Table 1. Measurements (in $\mathrm{mm}$ ) of the small theropod tibiae from the Late Jurassic of Tendaguru

\begin{tabular}{|c|c|c|c|c|c|}
\hline & Length & $\begin{array}{l}\text { Proximal } \\
\text { width }\end{array}$ & $\begin{array}{l}\text { Proximal } \\
\text { depth }\end{array}$ & $\begin{array}{l}\text { Distal } \\
\text { width }\end{array}$ & $\begin{array}{l}\text { Distal } \\
\text { depth }\end{array}$ \\
\hline $\begin{array}{l}\text { MB.R.1763 } \\
\text { ('Coelurosaurier A') }\end{array}$ & 163 & 17 & 30 & 25 & 11 \\
\hline $\begin{array}{l}\text { MB.R.1750 } \\
\text { ('Coelurosaurier B') }\end{array}$ & $209^{*}$ & - & - & 29 & 12 \\
\hline $\begin{array}{l}\text { MB.R.1751 } \\
\text { ('Coelurosaurier C') }\end{array}$ & 255 & 25 & 46 & 35 & 15 \\
\hline
\end{tabular}

Width refers to transverse width, depth refers to anteroposterior width.

* Length as preserved.

$\mathrm{B}$, and C'. Only very brief comments on the other small theropod material will be added.

\section{3.a. 'Coelurosaurier A'}

\section{3.a.1. Description}

This taxon is represented by an isolated right tibia (MB.R.1763; Figs 2, 3) from the stegosaur locality 'St' (Janensch, 1925). The element is $161 \mathrm{~mm}$ long and slender (for detailed measurements see Table 1). The shaft is slightly flexed, so that the lateral side is convex and the medial side concave. The cnemial crest is only moderately expanded, considerably higher proximodistally than long anteroposteriorly, and anteriorly and slightly proximally directed. It arises out of the anteromedial side of the tibial shaft, where it continues distally as a well-developed ridge for the proximal two-thirds of the bone. Proximally, the cnemial crest turns slightly laterally. The impression of this turn is pronounced by the presence of an oblique ridge on the lateral side of the anterior end of the cnemial crest. The medial condyle of the proximal articular end forms a crest medially that is continuous with the cnemial crest. The articular facet extends from this crest laterally onto the flat proximal surface of the fibular condyle. The fibular condyle consists of a larger, subspherical posterior condyle and a smaller, triangular anterior part and is offset from the cnemial crest anteriorly by a broad, U-shaped incision (Fig. 3a). It is considerably shorter than the medial condyle of the proximal end posteriorly, and is separated from the latter by a small, V-shaped gap. The medial condyle has a small, triangular, posteriorly pointing process. A small fibular crest was obviously present on the anterolateral side of the proximal shaft, but is largely eroded away. It was proximally placed, ending only $40 \mathrm{~mm}$ below the proximal end, short (c. $21 \mathrm{~mm}$ ), and slightly posteroproximally inclined. The crest is offset from the proximal end, but connected with the anterior end of the fibular condyle by a low, rounded edge. Distally from the fibular crest, a narrow, slightly concave facet runs over the anterolateral surface of the shaft distally and narrows towards its distal end. The shaft is triangular in outline in its central part, with a flat 

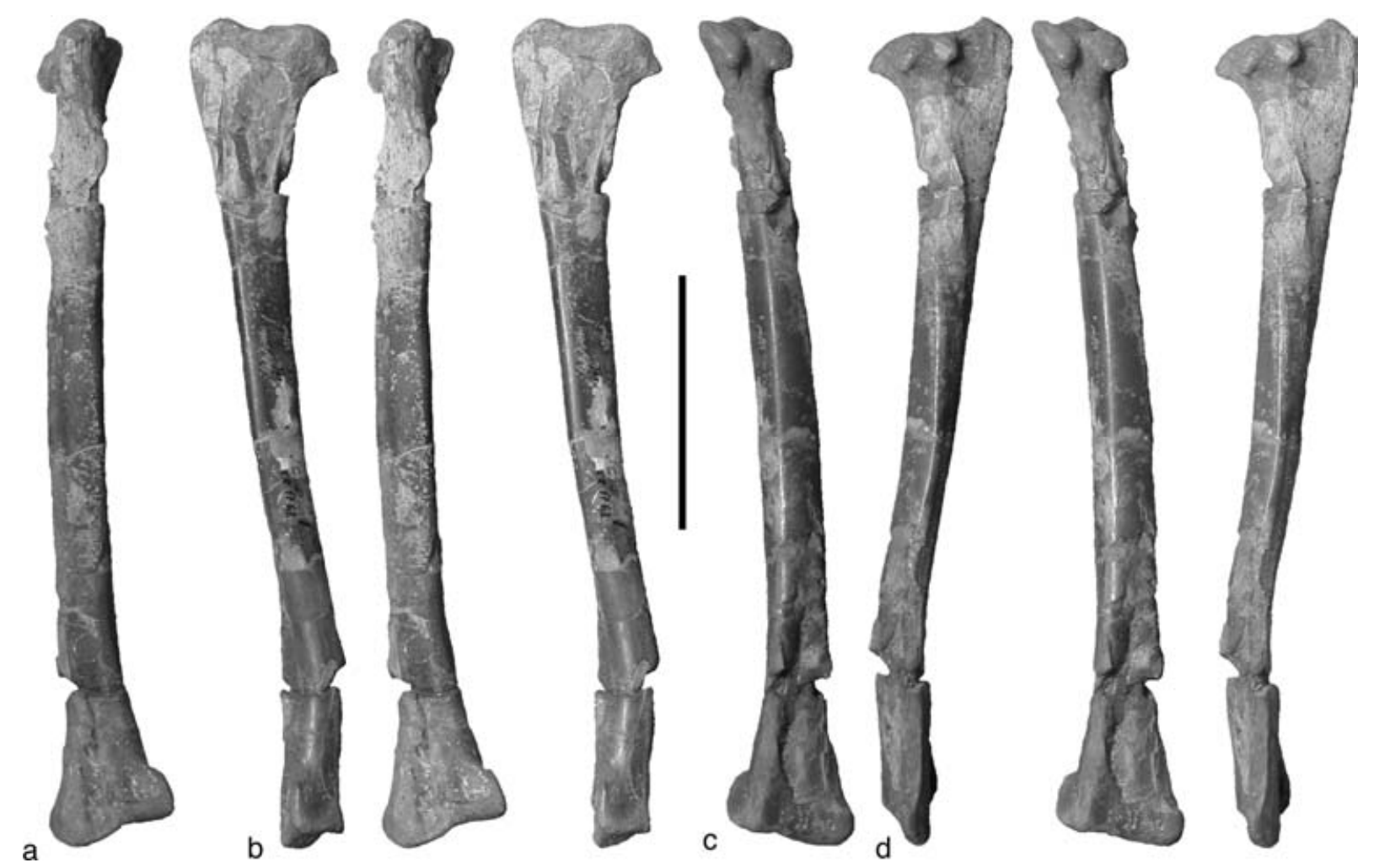

Figure 2. Isolated right tibia of a basal tetanuran theropod from the Late Jurassic of Tendaguru, Tanzania (MB.R.1763; 'Coelurosaurier A' of Janensch, 1925). (a) Anterior view (stereopair). (b) Medial view (stereopair). (c) Posterior view (stereopair). (d) Lateral view (stereopair). Scale bar is $50 \mathrm{~mm}$.

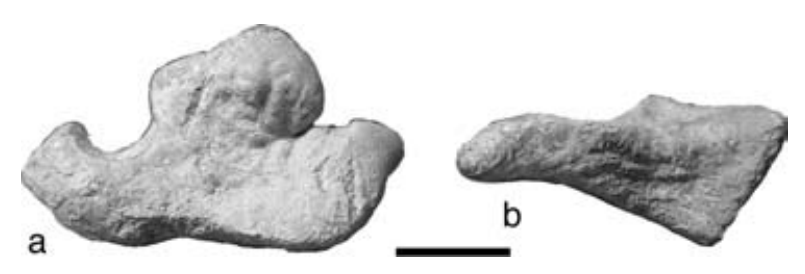

Figure 3. Isolated right tibia of a basal tetanuran theropod from the Late Jurassic of Tendaguru, Tanzania (MB.R.1763; 'Coelurosaurier A' of Janensch, 1925). (a) Proximal view. (b) Distal view. Scale bar is $10 \mathrm{~mm}$.

posterior surface that is offset from the slightly convex anterolateral side by a pronounced edge, but curves more smoothly into the convex medial side. Distally, the shaft becomes anteroposteriorly flattened. The distal articular end is triangular in outline, with a higher medial part and a long, slightly posteriorly flexed lateral part (Fig. 3b). The lateral malleolus extends slightly further distally than the medial and is gently convex transversely distally. The medial malleolus is flattened distally. On the anterior side, an almost vertical step subdivides the proximal part of the distal expansion into two subequal sides and sharply flexes medially distally. This step represents the proximomedial bracing for the ascending process of the astragalus and thus indicates that this process was restricted to the lateral half of the astragalus. On the anterior side of the lateral malleolus, a flat, slightly anterolaterally directed area indicates the connection with the distal end of the fibula.

\section{3.a.2. Phylogenetic position}

This tibia differs considerably from those of basal theropods, such as coelophysids (Raath, 1969; Rowe, 1989) and Dilophosaurus (Welles, 1984) in that the fibular condyle is offset from the cnemial crest by an U-shaped incision and reduced posteriorly, and the distal end is broadly triangular in outline, all synapomorphies that it shares with more derived theropods. It lacks the ceratosaurian synapomorphy of a hypertrophied cnemial crest (e.g. Janensch, 1925; Bonaparte, Novas \& Coria, 1990; Carrano, Sampson \& Forster, 2002) and shares the tetanuran synapomorphy of a fibular crest that is clearly offset from the proximal end of the bone (Rauhut, 2003a). This indicates that this element represents a member of the Tetanurae. The step on the anterior side of the distal end might be another tetanuran synapomorphy, since it is absent in basal theropods and small ceratosaurs, such as Elaphrosaurus (Janensch, 1925) and Masiakasaurus (Carrano, Sampson \& Forster, 2002). However, this step probably represents the reduced anterolateral part of the distal tibia of more basal theropods, and the situation in basal ceratosaurs and abelisaurs is unclear due to fusion of the tibia with the proximal tarsals in these animals. 
Within tetanurans, MB.R.1763 most probably represents a basal form, as indicated by the short and very proximally placed fibular crest, which is furthermore connected to the proximal end by a low, rounded ridge. This ridge might represent a remainder of the low crest that connects the fibular crest with the proximal end in basal theropods. An important difference from coelurosaurs is indicated by the step on the anterior side of the distal tibia. In all coelurosaurs, with the possible exception of the most basal forms (Rauhut \& $\mathrm{Xu}$, in press), the ascending process of the astragalus arises out of the entire breadth of the bone and covers the entire anterior surface of the distal tibia. The step in the tibia of 'Coelurosaurier A' indicates that it was restricted to the lateral half of the astragalar body, as in noncoelurosaurian theropods. Thus, MB.R.1763 represents a basal tetanuran, but most probably not a coelurosaur (sensu Gauthier, 1986), unless it was one of the most basal representatives of this clade.

\section{3.b. 'Coelurosaurier $B$ ' and ' $C$ '}

Janensch (1925, pp. 52-3) described a partial tibia, also from the stegosaur locality ' $\mathrm{St}$ ' in the Middle Saurian beds as 'Coelurosaurier B' (MB.R.1750; Figs 4e-h, $5 \mathrm{c}, \mathrm{d})$ and a complete, slightly larger element from the Upper Saurian beds of the locality ' $\mathrm{H}$ ' as 'Coelurosaurier C' (MB.R.1751; Figs 4a-d, 5a, b). Janensch (1925, p. 53) noted several slight differences, most notably that there is a sharp ridge extending proximally from the lateral malleolus on the lateral side in MB.R.1750. Other differences noted by Janensch, such as the more distally expanded lateral malleolus in MB.R.1750, and the slightly narrower facet for the ascending process of the astragalus and broader lateral facet for the contact with the fibula in MB.R.1751, might be due to differences in preservation or individual variation. Apart from these differences, MB.R.1750 was obviously not much shorter than MB.R.1751, but is considerably more slender. Whether these slight differences represent individual, sexual or taxonomic differences cannot be determined on the basis of the material available, but the two tibiae certainly represent closely related taxa and can thus be treated together here.

\section{3.b.1. Description}

The complete tibia MB.R.1751 ('Coelurosaurier C') is $257 \mathrm{~mm}$ long, whereas MB.R.1750 ('Coelurosaurier B') measures $209 \mathrm{~mm}$ as preserved, with an estimated 35-45 mm missing (for further measurements see Table 1). The shaft of MB.R.1751 is slightly flexed, so that it is convex laterally and concave medially, whereas the shaft of MB.R.1750 seems to be straight. The cnemial crest of MB.R.1751 ('Coelurosaurier C') is more strongly developed than in MB.R.1763 ('Coelurosaurier A'), but seemingly less so than in most ceratosaurs and basal tetanurans, although its exact extent cannot be determined due to erosion at the anterior end. The cnemial crest seems to be mainly anteriorly and very slightly laterally, and not or only very slightly proximally, directed. As in MB.R.1763 ('Coelurosaurier A'), there is a small, oblique ridge on the lateral side of the anterior expansion, but the cnemial crest is less clearly offset from the fibular condyle. The latter is damaged laterally, but seems to have been rectangular in outline and was offset from the medial condyle posteriorly by a wide, U-shaped intercondylar groove (Fig. 5a). The articular surface extends further proximally towards the medial margin of the proximal end, as in MB.R.1763 ('Coelurosaurier A'). Posteriorly, the medial condyle is rounded and lacks the small triangular process seen in MB.R.1763. A well-developed fibular crest was present, but is damaged in both specimens. It was proximally placed and connected to the anterior end of the fibular condyle by a low but sharply defined crest. In contrast to MB.R.1763 ('Coelurosaurier A'), there is no distally extended ridge below the cnemial crest on the anteromedial side in MB.R.1750 and 1751. The anterior side is flattened, resulting in the shaft being wider transversely than deep anteroposteriorly over most of its length. The posterolateral and posteromedial sides smoothly blend into each other, so that the shaft cross-section is semi-oval. At the lateral margin of the anterior side, a narrow flat to slightly concave area extends over most of the length of the shaft below the crista fibularis and indicates the attachment of the fibular shaft. The distal end is strongly flattened anteroposteriorly and expanded transversely, more to the lateral than to the medial side. The distal articular surface is broadly triangular in outline (Figs $5 b, c$ ). The anterior side of the distal end is flattened, with a broad, rectangular, vertical ridge that is confluent with the medial margin of the bone forming the medial border of the anterior facet for the ascending process of the astragalus. In the better preserved distal end of MB.R.1750 ('Coelurosaurier B'), a slightly depressed facet for the ascending process of the astragalus is present on the anterior surface (Fig. 5d). This facet is trapezoidal in outline, higher than wide and extends slightly further proximally on the lateral than on the medial side. The facet is subdivided by a low, rounded, vertical medial ridge. A very similar facet seems to have been present in MB.R.1751 ('Coelurosaurier C'), but has been largely obliterated by erosion. Lateral from the facet, the anterior side flexes slightly laterally for the flat surface that indicates the distal contact with the fibula. The lateral malleolus extends further distally than the medial and is distally convex. On the distal surface of the medial malleolus, a broad, welldeveloped groove extends from the mid-section of the distal articular surface posteromedially. This groove is present in both specimens, but better developed in MB.R.1750 ('Coelurosaurier B'). As noted above, a 


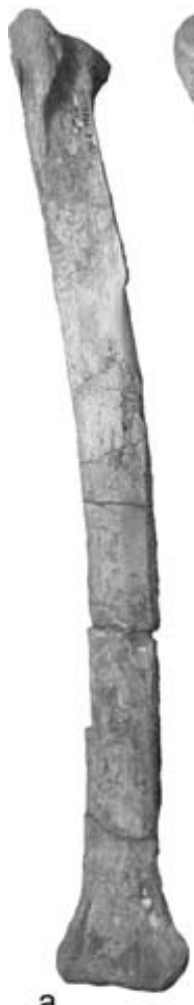

a

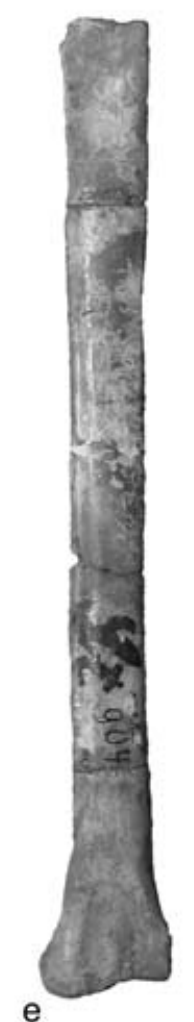

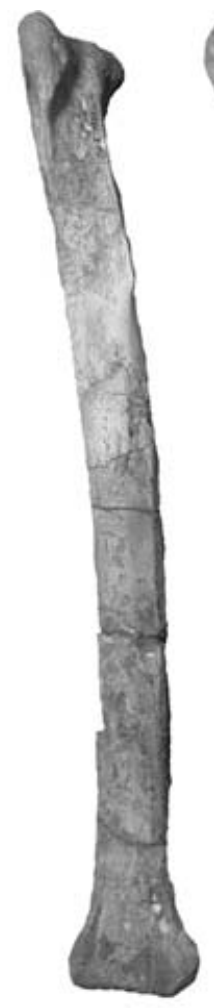
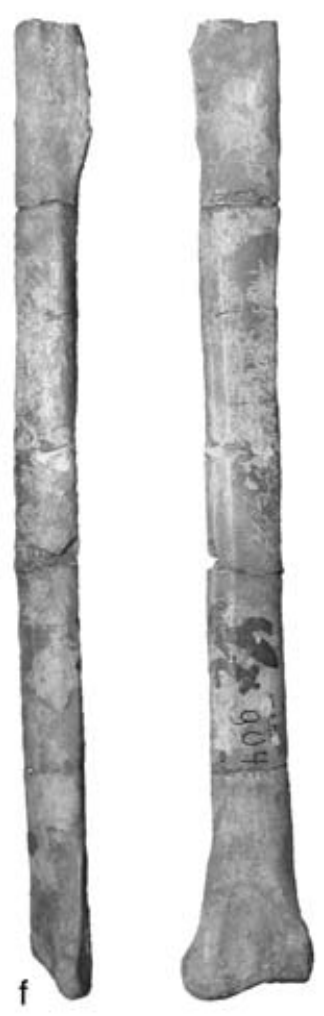
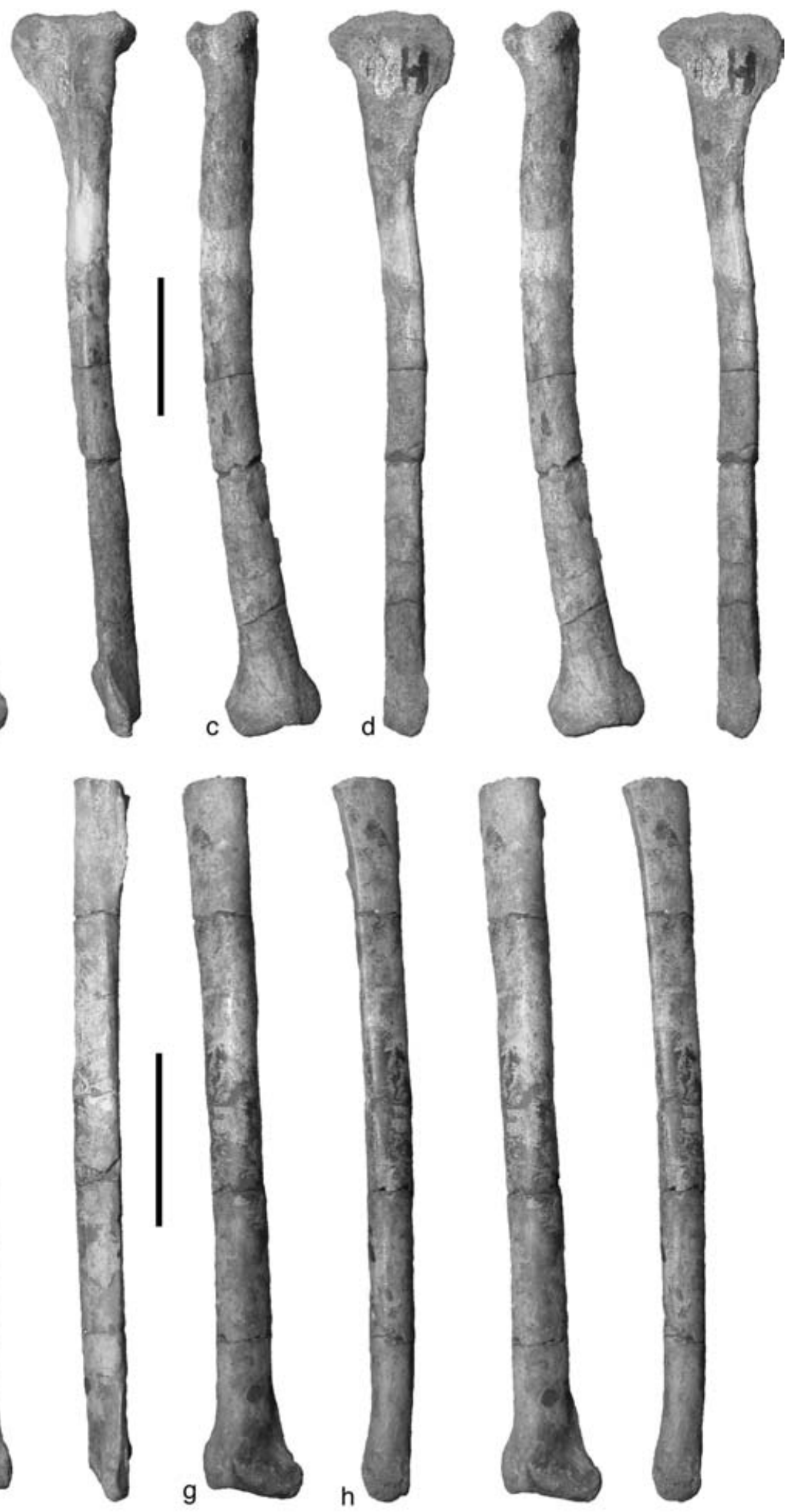

Figure 4. Isolated tibiae of small abelisauroids from the Late Jurassic of Tendaguru, Tanzania (top row: MB.R.1751; 'Coelurosaurier C' of Janensch, 1925; bottom row: MB.R.1750; 'Coelurosaurier B' of Janensch, 1925). (a) Anterior view (stereopair). (b) Lateral view (stereopair). (c) Posterior view (stereopair). (d) Medial view (stereopair). (e) Anterior view (stereopair). (f) Lateral view (stereopair). (g) Posterior view (stereopair). (h) Medial view (stereopair). Scale bars are $50 \mathrm{~mm}$. 


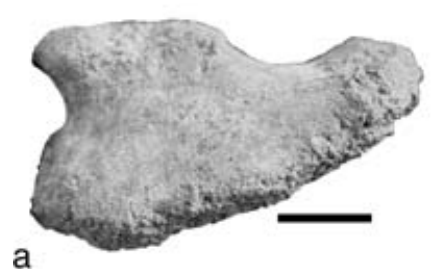

a

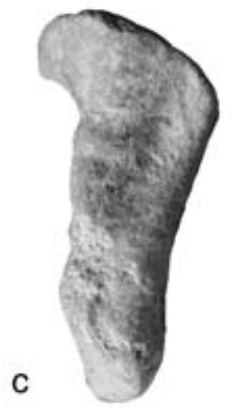

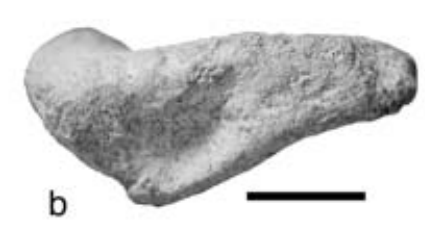

b

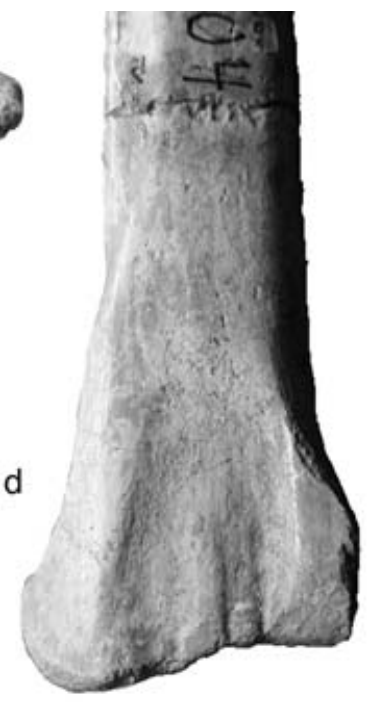

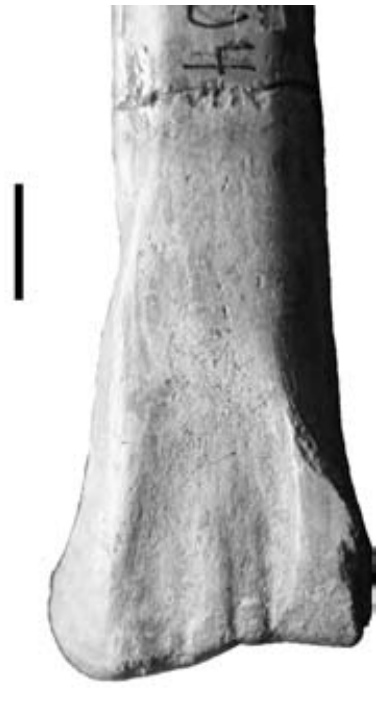

Figure 5. Isolated tibiae of small abelisauroids from the Late Jurassic of Tendaguru, Tanzania. (a, b) MB.R.1751 ('Coelurosaurier C' of Janensch, 1925). (a) Proximal view. (b) Distal view. (c, d) MB.R.1750 ('Coelurosaurier B' of Janensch, 1925). (c) Distal view (stereopair, slightly exaggerated to better illustrate morphology). (d) Anterior view of the distal end, illustrating facet for the ascending process of the astragalus (stereopair; exaggerated to better illustrate morphology). Scale bars are $10 \mathrm{~mm}$.

sharply defined ridge extends from the lateral malleolus proximally and disappears some $11 \mathrm{~mm}$ proximal of the facet for the ascending process of the astragalus.

\section{3.b.2. Phylogenetic position}

These two tibiae differ from those of basal theropods, such as coelophysids and Dilophosaurus, in that the distal end is anteroposteriorly compressed and triangular in outline. However, they differ from tetanurans in that the cnemial crest is less clearly offset from the fibular condyle and the fibular crest is connected to the proximal end. Within non-tetanuran theropods, an anteroposteriorly flattened distal end of the tibia with a flat anterior surface is only found in small ceratosaurs more derived than Ceratosaurus, such as Velocisaurus (Bonaparte, 1991b) and Masiakasaurus (Carrano, Sampson \& Forster, 2002). In more basal theropods, and theropod outgroups, the distal end of the tibia is round to oval in cross-section and the lateral end of the anterior side is incised for the ascending process of the astragalus. The situation in most abelisaurids is unclear, since no distal tibiae are known for Abelisaurus, Carnotaurus or Majungatholus, and the tibia is fused with the proximal tarsals in Xenotarsosaurus (Martínez et al. 1986). However, the anterior distal side of the tibia seems to have a pronounced oblique step in the abelisaurid Pycnonemosaurus (Kellner \& Campos, 2002), whereas in Rajasaurus, the anterior side of the distal tibia seems to be flat and has a depressed facet for the ascending process of the astragalus (Wilson et al. 2003), similar to that seen in MB.R.1750 ('Coelurosaurier B'). Thus, the flat anterior side of the distal tibia might be a synapomorphy of all abelisauroids, or of a possibly monophyletic clade of mainly small abelisaurs, the noasaurids (Coria \& Salgado, 2000; Carrano, Sampson \& Forster, 2002; Wilson et al. 2003), that is convergently present in Rajasaurus. The material from Tendaguru shares another apomorphic feature with abelisaurs, including at least some noasaurids. This is the broad medial vertical ridge on the anterior side of the distal end, which seems to be present in Velocisaurus (Bonaparte, 1991b), Masiakasaurus (Carrano, Sampson \& Forster, 2002), and the mediumsized, probable abelisaur Quilmesaurus (Coria, 2001). Such a ridge is absent in all other theropods, with the possible exception of Chilantaisaurus and spinosaurids (Rauhut, 2003a). The presence of both of these characters, in combination with the lack of tetanuran synapomorphies, in the two elements from Tendaguru indicates that they represent small abelisauroids (sensu Rauhut, 2003a).

\section{3.c. Other small theropod material from Tendaguru}

The other small theropod material from Tendaguru is very fragmentary and rather uninformative. The distal end of a left ischium MB.R.1756 from the Upper Saurian Beds shows that the distal ischium was expanded to form a moderate ischial 'boot' (Fig. 5). Within coelurosaurs, ischial boots are known only in a few ornithomimosaurs (Barsbold \& Osmólska, 1990), but very similar moderately expanded boots are present in all abelisaurs for which pelvic material is known (Janensch, 1925; Bonaparte, Novas \& Coria, 1990; Coria, Chiappe \& Dingus, 2002). This specimen comes from the same locality as the tibia MB.R.1751 and fits well in size and preservation with the latter and might thus represent the same taxon. 

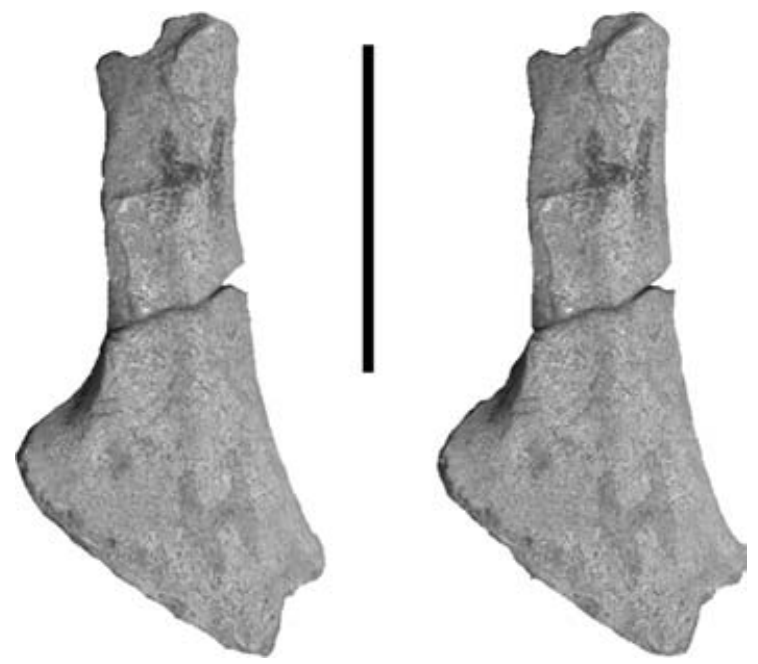

Figure 6. Distal end of a left ischium of an abelisauroid theropod from the Late Jurassic of Tendaguru, Tanzania; MB.R.1756. Lateral view (stereopair). Scale bar is $50 \mathrm{~mm}$.

\section{Discussion}

\section{4.a. Juveniles or small taxa?}

To evaluate the significance of the small theropod remains from Tendaguru, it must first be determined if the material represents truly small taxa or juveniles of larger species. Janensch (1920, 1925) described several taxa of large theropod, all based on very fragmentary material. Although the material is not diagnostic, and these species have to be considered nomina dubia (Rauhut, unpub. data), it can be noted that the large theropod fauna from Tendaguru includes at least one species of ceratosaur (Rowe \& Gauthier, 1990; Madsen \& Welles, 2000; Carrano, Sampson \& Forster, 2002) and two or more taxa of basal tetanuran (Janensch, 1925; Molnar, Kurzanov \& Dong, 1990; pers. obs.). Furthermore, Elaphrosaurus bambergi represents a species of medium-sized abelisauroid (Janensch, 1920, 1925; Holtz, 1994, 2000; Rauhut, 1998, 2003a).

The basal tetanuran tibia MB.R.1763 ('Coelurosaurier A') differs significantly from the type tibia of 'Allosaurus' tendagurensis (Janensch, 1925) and a slightly smaller and more slender tibia of large basal tetanurans (Janensch, 1925, pl. 6, Fig. 6) in the much less developed cnemial crest, the different shape of the fibular condyle and the cross-section of the proximal half of the shaft. The finished appearance of the articular ends furthermore indicates that this element is at least not derived from a hatchling or young juvenile and, given its small size, represents a rather small taxon. Thus, this specimen clearly indicates the presence of another, smaller taxon of basal tetanuran.

Likewise, MB.R.1751 ('Coelurosaurier C') differs from the tibiae of a large ceratosaur (MB.37 and MB.69; Janensch, 1925, pl. 6, Fig. 5) in the size and shape of the cnemial crest and the more anteroposteriorly com-
Table 2. Overview of different theropod taxa represented by comparable postcranial material from the Late Jurassic of Tendaguru

\begin{tabular}{|c|c|c|c|}
\hline $\begin{array}{l}\text { Specimen } \\
\text { number }\end{array}$ & Material & $\begin{array}{l}\text { Identification } \\
\text { in Janensch } \\
(1925)\end{array}$ & Identification here \\
\hline MB.R.1763 & Tibia & Coelurosaurier A & Basal tetanuran \\
\hline MB.R.1750 & Tibia & Coelurosaurier B & Abelisauroid \\
\hline MB.R.1751 & Tibia & Coelurosaurier C & Abelisauroid* \\
\hline MB.Tibia 67 & Tibia & $\begin{array}{l}\text { Allosaurus(?) } \\
\text { tendagurensis }\end{array}$ & Basal tetanuran \\
\hline MB.TL 42 & Tibia & Theropoda & Basal tetanuran \\
\hline MB.69 \& 37 & Tibiae & $\begin{array}{l}\text { ?Ceratosaurus } \\
\text { roechlingi }\end{array}$ & Basal ceratosaur \\
\hline MB.dd & $\begin{array}{l}\text { Partial } \\
\quad \text { skeleton }\end{array}$ & $\begin{array}{l}\text { Elaphrosaurus } \\
\text { bambergi }\end{array}$ & $\begin{array}{l}\text { Valid species; } \\
\text { basal abelisauroid }\end{array}$ \\
\hline
\end{tabular}

* Possibly the same taxon as MB.R.1750.

pressed distal end. The tibia of Elaphrosaurus differs significantly in the entire morphology of the proximal end (Janensch, 1925; Galton, 1982; Chure, 2001). The distal end of MB.R.1750 ('Coelurosaurier B') differs from the large ceratosaurian tibiae in the stronger anteroposterior compression and from both the large ceratosaur and Elaphrosaurus in the presence of a depressed, subdivided facet for the ascending process of the astragalus. Thus, these two elements also indicate the presence of at least one further taxon of ceratosaur in the theropod fauna of Tendaguru, apart from Elaphrosaurus and the large taxon represented by MB.37 and 69. It should be noted again that these elements come from different levels and are not contemporaneous, and thus they add only one additional taxon to their respective faunas, regardless of whether MB.R.1750 and 1751 represent the same, or two different taxa.

The question of whether these elements represent juvenile or adult theropods is more difficult to answer, partially due to the rather poor preservation of the more complete element MB.R.1751 ('Coelurosaurier C'). However, the distal end of MB.R.1750 ('Coelurosaurier B') shows well-finished bone surfaces and fine details of the articular end, indicating that again it is not a very young individual and thus probably represents a rather small taxon. The fact that neither MB.R.1750 nor MB.R.1751 has the proximal tarsals fused to the tibia, as is the case in other abelisaurs (Martínez et al. 1986; Carrano, Sampson \& Forster, 2002), might indicate, however, that these elements represent subadult rather than fully adult individuals.

For a summary of theropod taxa from Tendaguru represented by post-cranial remains, see Table 2 .

\section{4.b. Theropod faunal composition}

With the identification of at least one of small basal tetanuran taxon and one or more small abelisaur taxa, the theropod fauna of Tendaguru seems to have a rather different taxonomic composition from that of the Late 
Jurassic of North America and Europe. In the fauna of the Morrison Formation, small theropods are mainly represented by coelurosaurs, such as Coelurus and Ornitholestes (Marsh, 1879; Osborn, 1903; Ostrom, 1980), tyrannosauroids (Madsen, 1974; Foster \& Chure, 2000), and maniraptorans (Jensen \& Padian, 1989; Chure, 1994, 1995). Likewise, Late Jurassic small theropod faunas from Europe include the basal coelurosaur Compsognathus (Wagner, 1861; Bidar, Demay \& Thomel, 1972; Zinke, 1998), tyrannosaurs (Zinke, 1998; Rauhut, 2000, 2003b), and a variety of maniraptorans (Zinke, 1998; Rauhut, 2000). The only ceratosaurs identified from the Late Jurassic of the Northern Hemisphere so far are the medium-sized basal taxon Ceratosaurus (Marsh, 1884; Madsen \& Welles, 2000; Antunes \& Mateus, 2003) and a close relative of the medium-sized basal abelisauroid Elaphrosaurus (Galton, 1982; Chure, 2001). However, these taxa, especially the abelisauroid, seem to be very rare elements of the fauna.

The revision of small theropod skeletal elements from the Late Jurassic of Tendaguru does not reveal any evidence for the presence of coelurosaurs (sensu Gauthier, 1986) in the Late Jurassic of East Africa. With the presence of Elaphrosaurus, a probable close relative of Ceratosaurus (Rowe \& Gauthier, 1990; Madsen \& Welles, 2000), and at least one other, small ceratosaur, the medium-sized to small theropod fauna from the Late Jurassic of East Africa seems to be more dominated by ceratosaurs than by coelurosaurs. This is in general accordance with the abundance of ceratosaurs of all sizes in Cretaceous theropod faunas of the Southern Hemisphere and may indicate that these faunal associations might already have been established by the end of Jurassic time. However, more fossil evidence from the Late Jurassic of Gondwana is needed to test this hypothesis.

\section{4.c. Evolutionary and biogeographic aspects of the Tendaguru theropods}

Apart from their addition to the theropod fauna of the Late Jurassic of East Africa, the abelisaur remains from Tendaguru are also of significance for our understanding of small abelisaur origin and evolution. The small tibia MB.R.1750 ('Coelurosaurier B') shares the derived character of a depressed, subdivided facet for the ascending process of the astragalus with the holotype of the Middle Jurassic Australian theropod Ozraptor (Fig. 7; Long \& Molnar, 1998). This allows identification of the otherwise very poorly preserved holotype of Ozraptor as the oldest known representative of the Abelisauroidea. The presence of this clade already in the Bajocian of Australia not only indicates an early divergence of ceratosaurs from the lineage leading towards tetanurans, which is in general accordance with predictions on the basis of phylogenetic analyses (e.g. Sereno, 1999; Holtz,
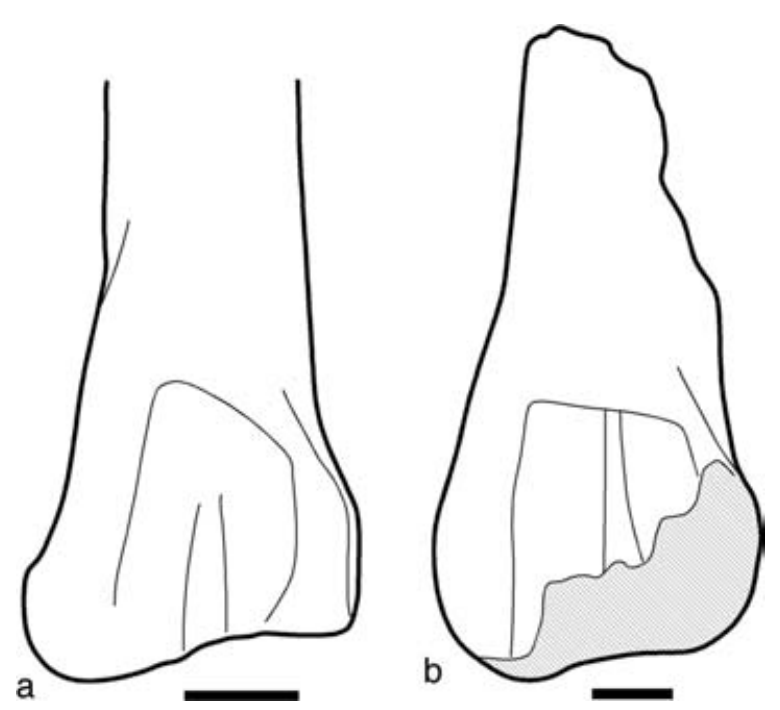

Figure 7. Comparison of the anterior side of the distal end of MB.R.1750 (a) and the type specimen of the Middle Jurassic Australian theropod Ozraptor (b). Not to scale; left tibia of Ozraptor reversed for comparison. Scale bars are $10 \mathrm{~mm}$.

1994; Rauhut, 2003a), but also an early divergence of ceratosaurids and abelisauroids within ceratosaurs. Indeed, if future analyses confirm the presence of a monophyletic clade of small abelisaurs that forms the sister group to abelisaurids (Coria \& Salgado, 2000; Carrano, Sampson \& Forster, 2002; Wilson et al. 2003), and the material from Tendaguru can be shown to belong to this clade, a Jurassic origin of abelisaurids must be postulated. This is in general accordance with recent evidence that suggests a preLate Cretaceous radiation of abelisaurids (Lamanna, Martínez \& Smith, 2002; Rauhut et al. 2003), in contrast to a diversification of this clade after the separation of Africa and South America, as originally hypothesized by Sampson et al. (1998).

So far, ceratosaurids are only known from the Late Jurassic of North America (Marsh, 1884; Madsen \& Welles, 2000), Europe (Antunes \& Mateus, 2003) and East Africa (Janensch, 1925; Rowe \& Gauthier, 1990; Madsen \& Welles, 2000), and the Early Cretaceous of Patagonia (Rauhut, 2004), whereas abelisauroids are well documented from the Late Jurassic of Africa (Holtz, 1994; Rauhut, 1998, 2003a; this work) and the Cretaceous of South America (e.g. Bonaparte, 1991a,b, 1996; Coria \& Salgado, 2000; Coria, 2001; Coria, Chiappe \& Dingus, 2002; Kellner \& Campos, 2002), India (Molnar, 1990; Chatterjee \& Rudra, 1996; Wilson et al. 2003), Madagascar (Sampson et al. 1998; Sampson, Carrano \& Forster, 2001), and Europe (Buffetaut, Mechin \& Mechin-Salessy, 1988; Accarie et al. 1995). The abelisaur record from the Cretaceous of Africa is still rather poor, although some fragmentary material has been reported recently (Russell, 1996), and fragmentary material described by Stromer (1934) as cf. Elaphrosaurus bambergi and some remains 
described by Stromer \& Weiler (1930) might also pertain to this clade (Carrano, Sampson \& Forster, 2002). Furthermore, Wilson et al. (2003) consider the putative coelurosaur Deltadromeus (Sereno et al. 1996) to be an abelisauroid, and recently described material from the Lower Cretaceous and lowermost Upper Cretaceous of Niger (Sereno, Wilson \& Conrad, 2004) greatly contributes to our knowledge of African abelisaurs. Cretaceous theropods from Australia are still poorly known, and only the genus Rapator, known from a single metacarpal (Huene, 1932), has been suggested to represent an abelisaur (Molnar, 1992). However, the small Early Cretaceous Australian theropod Kakuru has a flattened anterior side of the distal end of the tibia with a medial vertical ridge (Molnar \& Pledge, 1980), both characters that might be synapomorphies of small abelisauroids (see above). Thus, abelisauroids seem to have been present in the Cretaceous of Australia as well.

Thus, abelisauroids had a long evolutionary history that reaches back to at least the early Middle Jurassic period. However, the early history of this group is still poorly known, mainly due to the poor late Early and Middle Jurassic dinosaur fossil record (see, e.g. Weishampel, 1990). Furthermore, current evidence suggests that the origin of abelisauroids might be found in Gondwana, for which the theropod fossil record is poorer still than for the Northern Hemisphere (Rauhut, 2003a). By Late Jurassic times, ceratosaurs, including abelisauroids, had diversified and represented an important faunal element of Gondwanan theropod faunas. By that time, the evolutionary pathways of the non-avian theropod faunas from the Northern and Southern hemispheres had probably already separated, with coelurosaurs of all sizes becoming the dominant theropods in the north, whereas large and small abelisauroids seem to have been important faunal elements in the Cretaceous theropod faunas of all southern continents. As noted by Buffetaut (1989) and Le Loeuff (1991), the European Cretaceous theropod fauna seems to have been a mixture of more typical Gondwanan and Laurasian elements.

Acknowledgements. Adriana López-Arbarello is thanked for critical discussions. The manuscript benefited from critical comments by Jeff Wilson and Tom Holtz, and Jane Holland is thanked for handling the MS. This work is part of DFG (German Research Foundation) project RA 1012/11 and the author is currently supported by the DFG under project RA 1012/2-1, which is gratefully acknowledged.

\section{References}

Aberhan, M., Bussert, R., HeInRICH, W.-D., SchranK, E., SchultKa, S., SAMES, B., Kriwet, J. \& Kapilima, S. 2002. Palaeoecology and depositional environments of the Tendaguru Beds (Late Jurassic to Early Cretaceous, Tanzania). Mitteilungen aus dem Museum für Naturkunde Berlin, Geowissenschaftliche Reihe 5, 1944.
ACCARIE, H., BeAudoin, B., DeJAX, J., Friès, G., Michard, J.-G. \& TAQuet, P. 1995. Découverte d'un Dinosaure Théropode nouveau (Genusaurus sisteronis n. g., n. sp.) dans l'Albien marin de Sisteron (Alpes de HauteProvence, France) et extension au Crétacé inférieur de la lignée cératosaurien. Comptes Rendus de l'Académie des Sciences de Paris, Séries II 320, 327-34.

Antunes, M. T. \& Mateus, O. 2003. Dinosaurs of Portugal. Comptes Rendus Palevol 2, 77-95.

BARSBOLD, R. \& OSMÓlSKA, H. 1990. Ornithomimosauria. In The Dinosauria (eds D. B. Weishampel, P. Dodson and H. Osmólska), pp. 225-44. Berkeley: University of California Press.

BidAR, A., DEMAY, L. \& ThOMEL, G. 1972. Compsognathus corallestris, nouvelle espèce de dinosaurien théropode du Portlandien de Canjuers (Sud-est de la France). Annales du Muséum d'Histoire Naturelle de Nice 1,940.

BONAPARTE, J. F. 1985. A horned Cretaceous carnosaur from Patagonia. National Geographic Research 1, 149-51.

BONAPARTE, J. F. 1991a. The Gondwanian theropod families Abelisauridae and Noasauridae. Historical Biology 5, $1-25$.

BONAPARTE, J. F. 1991b. Los vertebrados fosiles de la Formacion Rio Colorado, de la ciudad de Neuquen y cercanias, Cretacio superior, Argentina. Revista del Museo Argentino de Ciencias Naturales "Bernardino Rivadavia", Paleontología 4, 15-123.

BONAPARTE, J. F. 1996. Cretaceous tetrapods of Argentina. Münchener Geowissenschaftliche Abhandlungen (A) 30, 73-130.

Bonaparte, J. F., Novas, F. E. \& Coria, R. A. 1990. Carnotaurus sastrei Bonaparte, the horned, lightly built carnosaur from the Middle Cretaceous of Patagonia. Contributions in Science 416, 1-42.

BufFETAUT, E. 1989. Archosaurian reptiles with Gondwanan affinities in the Upper Cretaceous of Europe. Terra Nova 1, 69-74.

Buffetaut, E., MEChin, P. \& Mechin-SAlessy, A. 1988. Un dinosaure théropode d'affinités gondwanniennes dans le Crétacé supérieur de Provence. Comptes Rendus de l'Académie des Sciences de Paris, Série II 306, 153-8.

Carrano, M. T., Sampson, S. D. \& Forster, C. A. 2002. The osteology of Masiakasaurus knopfleri, a small abelisauroid (Dinosauria: Theropoda) from the Late Cretaceous of Madagascar. Journal of Vertebrate Paleontology 22, 510-34.

ChatterJee, S. \& RudrA, D. K. 1996. KT events in India: impact, rifting, volcanism and dinosaur extinction. Memoirs of the Queensland Museum 39, 489-532.

ChURE, D. J. 1994. Koparion douglassi, a new dinosaur from the Morrison Formation (Upper Jurassic) of Dinosaur National Monument; the oldest troodontid (Theropoda: Maniraptora). Brigham Young University Geology Studies 40, 11-15.

ChuRE, D. J. 1995. The teeth of small theropods from the Morrison Formation (Upper Jurassic: Kimmeridgian), UT. Journal of Vertebrate Paleontology 15, 23A.

ChuRE, D. J. 2001. The second record of the African theropod Elaphrosaurus (Dinosauria, Ceratosauria) from the Western Hemisphere. Neues Jahrbuch für Geologie und Paläontologie, Monatshefte 2001, 565-76.

CORIA, R. A. 2001. New theropod from the Late Cretaceous of Patagonia. In Mesozoic vertebrate life (eds D. H. Tanke and K. Carpenter), pp. 3-9. Bloomington \& Indianapolis: Indiana University Press. 
Coria, R. A., Chiappe, L. M. \& Dingus, L. 2002. A new close relative of Carnotaurus sastrei Bonaparte 1985 (Theropoda: Abelisauridae) from the Late Cretaceous of Patagonia. Journal of Vertebrate Paleontology 22, $460-5$.

CORIA, R. A. \& SAlgADO, L. 1995. A new giant carnivorous dinosaur from the Cretaceous of Patagonia. Nature 377, 224-6.

CoRIA, R. A. \& SAlgado, L. 2000. A basal Abelisauria Novas, 1992 (Theropoda-Ceratosauria) from the Cretaceous of Patagonia, Argentina. Gaia 15, 89-102.

Foster, J. R. \& Chure, D. J. 2000. An ilium of a juvenile Stokesosaurus (Dinosauria, Theropoda) from the Morrison Formation (Upper Jurassic: Kimmeridgian), Meade County, South Dakota. Brigham Young University, Geology Studies 45, 5-10.

GALTON, P. M. 1982. Elaphrosaurus, an ornithomimid dinosaur from the Upper Jurassic of North America and Africa. Paläontologische Zeitschrift 56, 265-75.

GAUTHIER, J. 1986. Saurischian monophyly and the origin of birds. Memoirs of the California Academy of Science $\mathbf{8}$, $1-55$.

HOLTZ, T. R. JR. 1994. The phylogenetic position of the Tyrannosauridae: implications for theropod systmatics. Journal of Paleontology 68, 1100-17.

HOLTZ, T. R. JR. 2000. A new phylogeny of the carnivorous dinosaurs. Gaia 15, 5-61.

Huene, F. v. 1932. Die fossile Reptil-Ordnung Saurischia, ihre Entwicklung und Geschichte. Monographien zur Geologie und Palaeontologie (Serie 1) 4, 1-361.

JANENSCH, W. 1914. Übersicht über die Wirbeltierfauna der Tendaguruschichten, nebst einer kurzen Charakterisierung der neu aufgeführten Arten von Sauropoden. Archiv für Biontologie 3, 81-110.

JANENSCH, W. 1920. Ueber Elaphrosaurus bambergi und die Megalosaurier aus den Tendaguru-Schichten Deutsch-Ostafrikas. Sitzungsberichte der Gesellschaft naturforschender Freunde zu Berlin 1920, 22535.

JANENSCH, W. 1925. Die Coelurosaurier und Theropoden der Tendaguru-Schichten Deutsch-Ostafrikas. Palaeontographica, Supplement VII, 1-99.

JANENSCH, W. 1929. Ein aufgestelltes und rekonstruiertes Skelett von Elaphrosaurus bambergi. Mit einem Nachtrag zur Osteologie dieses Coelurosauriers. Palaeontographica, Supplement VII, 279-86.

JENSEN, J. A. \& PADIAN, K. 1989. Small pterosaurs and dinosaurs from the Uncompahgre fauna (Brushy Basin Member, Morrison Formation: ?Tithonian), Late Jurassic, western Colorado. Journal of Paleontology 63, 364-73.

Kellner, A. W. A. \& CAmpos, D. A. 2002. On a new theropod dinosaur (Abelisauria) from the continental Cretaceous of Brazil. Arquivos do Museu Nacional 60, 163-70.

Lamanna, M. C., Martínez, R. D. \& Smith, J. B. 2002. A definitive abelisaurid theropod dinosaur from the early Late Cretaceous of Patagonia. Journal of Vertebrate Paleontology 22, 58-69.

LE LoEUfF, J. 1991. The Campano-Maastrichtian vertebrate faunas from southern Europe and their relationships with other faunas in the world; palaeobiogeographical implications. Cretaceous Research 12, 93-114.

LONG, J. A. \& MOLNAR, R. E. 1998. A new Jurassic theropod dinosaur from western Australia. Records of the Western Australian Museum 19, 121-9.
MAdSEN, J. H. 1974. A new theropod dinosaur from the Upper Jurassic of Utah. Journal of Paleontology 48, $27-31$.

Madsen, J. H. J. \& Welles, S. P. 2000. Ceratosaurus (Dinosauria, Theropoda). A revised osteology. Miscellaneous Publication, Utah Geological Survey 00-2, 1-80.

MAIER, G. 2003. African dinosaurs unearthed: the Tendaguru expeditions. Bloomington and Indianapolis: Indiana University Press, $512 \mathrm{pp}$.

MARSH, O. C. 1879. Notice of new Jurassic reptiles. American Journal of Science (series 3) 18, 501-5.

MARSH, O. C. 1884. Principal characters of American Jurassic dinosaurs. Part VIII. The order Theropoda. American Journal of Science (series 3) 27, 32940.

MARTinez, R., Gimenez, O., Rodriguez, J. \& Bochatey, G. 1986. Xenotarsosaurus bonapartei nov. gen. et sp. (Carnosauria, Abelisauridae), un nuevo Theropoda de la Formación Bajo Barreal, Chubut, Argentina. Actas del IV Congreso Argentino de Paleontologia y Biostratigrafia 2, 23-31.

MOLNAR, R. E. 1990. Problematic Theropoda: "Carnosaurs". In The Dinosauria (eds D. B. Weishampel, P. Dodson and H. Osmólska), pp. 306-17. Berkeley: University of California Press.

MOLNAR, R. E. 1992. Paleozoogeographic relationships of Australian Mesozoic tetrapods. In New concepts in global tectonics (eds S. Chatterjee and N. I. Hotton), pp. 259-66. Lubbock: Texas Tech University Press.

Molnar, R. E., Kurzanov, S. M. \& DONG, Z. 1990. Carnosauria. In The Dinosauria (eds D. B. Weishampel, P. Dodson and H. Osmólska), pp. 169-209. Berkeley: University of California Press.

Molnar, R. E. \& Pledge, N. S. 1980. A new theropod dinosaur from South Australia. Alcheringa 4, 281-7.

NopCSA, F. 1928. The genera of reptiles. Palaeobiologica $\mathbf{1}$, $163-88$.

NovAs, F. E. 1996. Alvarezsauridae, Cretaceous basal birds from Patagonia and Mongolia. Memoirs of the Queensland Museum 39, 675-702.

NovAs, F. E. 1997. South American dinosaurs. In Encyclopedia of dinosaurs (eds P. J. Currie and K. Padian), pp. 678-89. San Diego: Academic Press.

OsBORN, H. F. 1903. Ornitholestes hermanni, a new compsognathoid dinosaur from the Upper Jurassic. Bulletin of the American Museum of Natural History 19, 459-64.

Ostrom, J. H. 1980. Coelurus and Ornitholestes; are they the same? In Aspects of vertebrate history (ed. L. L. Jacobs), pp. 245-56. Flagstaff: Museum of Northern Arizona Press.

RAATH, M. A. 1969. A new coelurosaurian dinosaur from the Forest Sandstone of Rhodesia. Arnoldia 4, 1-25.

Rauhut, O. W. M. 1995. Zur systematischen Stellung der afrikanischen Theropoden Carcharodontosaurus Stromer 1931 und Bahariasaurus Stromer 1934. Berliner geowissenschaftliche Abhandlungen (E) 16.1, 35775.

RAUHUT, O. W. M. 1998. Elaphrosaurus bambergi and the early evolution of theropod dinosaurs. Journal of Vertebrate Paleontology 18, 71A.

RAUHUT, O. W. M. 1999. A dinosaur fauna from the Upper Cretaceous (Cenomanian) of northern Sudan. Palaeontologia africana 35, 61-84.

Rauhut, O. W. M. 2000. The dinosaur fauna from the Guimarota mine. In Guimarota. A Jurassic Ecosystem 
(eds T. Martin and B. Krebs), pp. 75-82. Munich: Verlag Dr. Friedrich Pfeil.

Rauhut, O. W. M. 2003a. The interrelationships and evolution of basal theropod dinosaurs. Special Papers in Palaeontology 69, 213 pp.

RauhuT, O. W. M. 2003b. A tyrannosauroid dinosaur from the Late Jurassic of Portugal. Palaeontology 46, 903-10.

RauHuT, O. W. M. 2004. Provenance and anatomy of Genyodectes serus, a large-toothed ceratosaur (Dinosauria: Theropoda) from Patagonia. Journal of Vertebrate Paleontology 24, 894-902.

Rauhut, O. W. M., Cladera, G., Vickers-Rich, P. \& RICH, T. H. V. 2003. Dinosaur remains from the Lower Cretaceous of the Chubut Group, Argentina. Cretaceous Research 24, 487-97.

Rauhut, O. W. M. \& XU, X. in press. The small theropod dinosaurs Tugulusaurus and Phaedrolosaurus from the Early Cretaceous of Xinjiang, China. Journal of Vertebrate Paleontology.

RICH, T. H. \& VICKERS-RICH, P. 1994. Neoceratopsians and ornithomimosaurs: dinosaurs of Gondwana origin. National Geographic Research and Exploration 10, 129-31.

RowE, T. 1989. A new species of the theropod dinosaur Syntarsus from the Early Jurassic Kayenta Formation of Arizona. Journal of Vertebrate Paleontology 9, 125-36.

Rowe, T. \& GAUTHIER, J. 1990. Ceratosauria. In The Dinosauria (eds D. B. Weishampel, P. Dodson and H. Osmólska), pp. 151-68. Berkeley: University of California Press.

Russell, D. A. 1972. Ostrich dinosaurs from the Late Cretaceous of western Canada. Canadian Journal of Earth Sciences 9, 375-402.

Russell, D. A. 1996. Isolated dinosaur bones from the Middle Cretaceous of the Tafilalt, Morocco. Bulletin du Muséum National d'Histoire Naturelle deParis, Série 4 18, 349-63.

Russell, D. A., Béland, P. \& McIntosh, J. S. 1980. Paleoecology of the dinosaurs of Tendaguru (Tanzania). Mémoires de la Societé géologique de la France, Nouvelle Série 139, 169-75.

Sampson, S. D., Carrano, M. T. \& Forster, C. A. 2001. A bizarre predatory dinosaur from the Late Cretaceous of Madagascar. Nature 409, 504-6.

SAmpson, S. D., Witmer, L. M., Forster, C. A., Krause, D. W., O'CONNOR, P. M., DODSON, P. \& RAVOAVY, F. 1998. Predatory dinosaur remains from Madagascar: implications for the Cretaceous biogeography of Gondwana. Science 280, 1048-51.

SERENO, P. C. 1999. The evolution of dinosaurs. Science 284, 2137-47.

Sereno, P. C., Beck, A. L., Dutheil, D. B., Gado, B., Larsson, H. C. E., LyOn, G. H., Marcot, J. D., Rauhut, O. W. M., Sadleir, R. W., Sidor, C. A., VARriCChIO, D. J., Wilson, G. P. \& WiLSON, J. A. 1998.
A long-snouted predatory dinosaur from Africa and the evolution of the spinosaurids. Science 282, 1298 1302.

Sereno, P. C., Dutheil, D. B., IARochene, M., Larsson, H. C. E., Lyon, G. H., MAGWENe, P. M., Sidor, C. A., VARricchio, D. J. \& Wilson, J. A. 1996. Predatory dinosaurs from the Sahara and Late Cretaceous faunal differentiation. Science 272, 986-91.

Sereno, P. C., Wilson, J. A. \& Conrad, J. L. 2004. New dinosaurs link southern landmasses in the MidCretaceous. Proceedings of the Royal Society of London, B, FirstCite online publication (www.journals.royalsoc.ac.uk).

Sereno, P. C., Wilson, J. A., LARSSON, H. C. E., Dutheil, D. B. \& SUES, H.-D. 1994. Early Cretaceous dinosaurs from the Sahara. Science 265, 267-71.

STROMER, E. 1934. Ergebnisse der Forschungsreisen Prof. E. Stromers in den Wüsten Ägyptens. II. Wirbeltierreste der Baharije-Stufe (unterstes Cenoman). 13. Dinosauria. Abhandlungen der Bayerischen Akademie der Wissenschaften, Mathematisch-naturwissenschaftliche Abteilung, Neue Folge 22, 1-79.

Stromer, E. \& WeILER, W. 1930. Ergebnisse der Forschungsreisen Prof. E. Stromers in den Wüsten Ägyptens. VI. Beschreibung von Wirbeltier-Resten aus dem nubischen Sandsteine Oberägyptens und aus ägyptischen Phosphaten nebst Bemerkungen über die Geologie der Umgebung von Mahamîd in Oberägypten. Abhandlungen der Bayerischen Akademie der Wissenschaften, Mathematisch-naturwissenschaftliche Abteilung, Neue Folge 7, 3-42.

WAGNER, A. 1861. Neue Beiträge zur Kenntnis der urweltlichen Fauna des lithographischen Schiefers. Schildkröten und Saurier aus dem lithographischen Schiefer. Abhandlungen der Bayerischen Akademie der Wissenschaften 9, 67-124.

WeIsHAMPEL, D. B. 1990. Dinosaurian distribution. In The Dinosauria (eds D. B. Weishampel, P. Dodson and H. Osmólska), pp. 63-139. Berkeley: University of California Press.

Welles, S. P. 1984. Dilophosaurus wetherilli (Dinosauria, Theropoda). Osteology and comparisons. Palaeontographica A 185, 85-180.

Wilson, J. A., Sereno, P. C., SRIVAstaVa, S., Bhatt, D. K., Khosla, A. \& SAHni, A. 2003. A new abelisaurid (Dinosauria, Theropoda) from the Lameta Formation (Cretaceous, Maastrichtian) of India. Contributions from the Museum of Paleontology, University of Michigan 31, 1-42.

Zils, W., Werner, C., Moritz, A. \& SaAne, C. 1995. Orientierende Tendaguru-Expedition 1994. Berliner geowissenschaftliche Abhandlungen (E) 16.2, 483-531.

ZINKE, J. 1998. Small theropod teeth from the Upper Jurassic coal mine of Guimarota (Portugal). Paläontologische Zeitschrift 72, 179-89. 